\title{
PERANAN PERGURUAN TINGGI DALAM RANGKA PENGEMBANGAN TEKNOLOGI TEPAT GUNA DAN KELEMBAGAAN POSYANTEK
}

\author{
Fitridawati Soehardi 1 \\ Universitas lancang Kuning pekanbaru \\ Emai: fitridawati@unilak.ac.id
}

\begin{abstract}
ABSTRAK
Berdasarkan Peraturan Menteri Dalam Negeri No 20 Tahun 2010 Pos Pelayanan Teknologi, atau Posyantek, adalah lembaga pelayanan teknologi tepat guna yang disarankan agar dibentuk di setiap kecamatan. Posyantek diharapkan dapat menjembatani kepentingan masyarakat terhadap teknologi tepat guna, sehingga inovasi di masyarakat khususnya usaha mikro kecil menengah dapat menikmati manfaatnya. Walaupun telah dikuatkan oleh Peraturan Menteri hanya beberapa wilayah di Indonesia yang melaksanakan kebijakan ini, diantaranya adalah Kabupaten Indragiri Hulu. Didasari oleh kebijakan pemerintah kabupaten, setiap kecamatan membentuk Posyantek dan salah satu diantaranya adalah Posyantek Bina Usaha di Kecamatan Pasir Penyu. Posyantek Bina Usaha mampu membuktikan keberlanjutannya sebagai unit pendamping UMKM di kecamatan dan menjadi inspirasi bagi Posyantek lain. Melalui studi kasus, langkah tindak mereka dalam menyelenggarakan fungsi intermediasi bagi usaha mikro kecil menengah dipelajari. Diskusi terarah dan wawancara mendalam dilakukan terhadap pengurus Posyantek dan kelompok usaha yang didampingi untuk mengenali peran lembaga tersebut khususnya dalam mendukung pengembangan inovasi masyarakat. Dapat disimpulkan bahwa kemampuan Posyantek Bina Usaha dalam memanfaatkan berbagai keunggulan yang ada didaerahnya menjadi salah satu hal pokok yang menentukan keberhasilan mereka. Unsur penting yang dapat didayagunakan adalah pemerintah, UMKM, perguruan tinggi, dan masyarakat. Selanjutnya, unsur tim pengurus dan organisasi yang dibangun berdasarkan musyawarah dengan wakil masyarakat pun menentukan, sehingga unit ini diterima sebagai bagian penting dalam aspek kehidupan masyarakat di kecamaan pasir penyu. Terwujudnya jalinan kerjasama dengan perguruan tinggi dan pihak swata dalam menjembatani kebutuhan teknologi tepat guna menegaskan peran strategis Pos Pelayanan Teknologi Tepat Guna sangat potensial sebagai unsur penting dalam pengembangan inovasi teknologi tepat guna secara nasional.
\end{abstract}

Kata kunci : Posyantek, Teknologi Tepat Guna, Perguruan tinggi.

\section{PENDAHULUAN}

Indonesia menduduki peringkat 51 dari 140 negara dalam hal daya saing bangsa (Anonimus, 2015). Pengentasan kemiskinan masih merupakan tujuan utama dalam perekonomian dan pembangunan bangsa Indonesia. Undang Undang No 18 tahun 2002 yang diterbitkan oleh Kementerian Riset dan Teknologi tentang Sistem Nasional Penelitian, Pengembangan dan Penerapan Ilmu Pengetahuan dan Teknologi merupakan satu dari kebijakan-kebijakan pemerintah yang mendukung program tersebut.

Peraturan Menteri Dalam Negeri No 10 tahun 2010 merupakan suatu kebijakan dalam bentuk kelembagaan yg berperan aktif dalam membantu pemerintah dalam memerangi kemiskinan dengan cara menganjurkan pembentukan Pos Pelayanan Teknologi atau Posyantek di setiap kecamatan. Peraturan merupakan pelaksanaan dari Instruksi Presiden No 3 tahun 2001. Pembentukan Posyantek merupakan suatu usaha 
dalam mendekatkan masyarakat terhadap sumber-sumber teknologi tepat guna, jika pelaksanaannya dapat diterapkan semua daerah di Indonesia. Maka secara tidak langsung akan terjadi peningkatan yang bertahap dalam penguasaan ilmu pengetahuan dan teknologi secara nasional. Posyantek diharapkan dapat menjadi perangkat kelembagaan penting di masyarakat yang mampu menjembatani kebutuhan masyarakat dengan pihak-pihak terkait yang melalui keterhubungan tersebut akan memicu kreatifitas dan inovasi masyarakat(Carolina,2014).

Posyantek sebagai lembaga yang efektif dalam membangkitkan kretifitas dan inovasi masyarakat dibidang teknologi tepat guna. Dalam perkembangannya peran serta perguruan tinggi mempunyai peluang cukup besar dalam membantu pengembangan teknologi tepat guna maupun kelembagaan posyantek. Perguruan tinggi mempunyai kemampuan dalam membantu merealisasikan inovasi posyantek baik itu berupa teknologi teknologi tepat guna maupun pemikiran-pemikiran yang berguna bagi pengembangan kelembagaan posyantek.

Mengacu pada peluang peran serta perguruan tinggi dalam pengembangan teknologi tepat guna dan kelembagaan posyatek sehingga dilakukan kajian terhadap Posyantek Bina Usaha yang memiliki wilayah kerja Kecamatan Pasir Penyu di Kabupaten Indragiri Hulu. Posyantek dibentuk tahun 2012 ini telah mendapatkan berbagai penghargaan ditingkat lokal maupun nasional. Melalui kajian terhadap kinerja posyantek Bina Usaha diharapkan akan diperoleh hasil yang dapat digunakan oleh perguruan tinggi dan pemangku kepentingan dalam pengembangan dan pembentukan Posyantek yang mampu menjalankan perannya sebagai pendamping dalam pengembangan inovasi masyarakat khususnya usaha mikro kecil menengah (UMKM).

\section{METODE}

Penelitian ini dilakukan dengan melakukan pengumpulan data sekunder menggunakan metode survey langsung di wilayah kerja posyantek Bina Usaha di Kecamatan Pasir Penyu Kabupaten Indragiri Hulu yang dilaksanakan dalam rentang waktu 6 (enam) bulan di tahun 2016 yaitu untuk mendapatkan data profil posyantek dan studi literature. Pengumpulan data primer dilakukan dengan melakukan Focus Group Discussion (FGD) dan wawancara. Responden adalah pengurus posyantek Bina Usaha dan 3 kelompok usaha yang memperoleh manfaat Posyantek. Ketiga kelompok usaha 
tersebut bergerak di bidang kerajinan, pembuatan bahan bangunan dan pengolahan makanan.

\section{Cara Analisis data}

Data-data yang diperoleh dari hasil survey dilapangan dan hasil FGD serta wawancara dengan responden kemudian dijadikan acuan penguatan mengenai kapasitas pendampingan dan pelayanan yang diberikan oleh Posyantek. Data dan informasi yang diperoleh dianalisis dengan menggunakan metode deskriptif. Sehingga dapat dianalisa kemampuan posyantek dalam mengembangkan teknologi tepat guna dan kelembagaannya dan peran serta kalangan akademisi dalam pengembangan posyantek.

\section{HASIL DAN PEMBAHASAN}

\subsection{Profil Posyantek.}

Posyantek Bina Usaha berdiri tanggal 9 januari 2012 dan mempunyai wilayah kerja meliputi 8 desa dan 5 kelurahan. Kepengurusan Posyantek Bina Usaha terdiri dari ketua, sekretaris, bendahara dan seksi-seksi dibidang pengembangan Teknologi Tepat Guna, kemitraan dan pelayanan Teknologi Tepat Guna dan Usaha. Pembinaan langsung dilakukan dibawah kepemimpinan Camat Pasir Penyu. Posyantek Bina Usaha membina 3 kelompok usaha dibidang kerajinan pembuatan lantai keramik dari batok, alat cetak Batu Bata dan pembuatan kerupuk sagu.

\subsection{Hasil FGD dan wawancara}

Permasalahan dalam pengembangan Posyantek dilapangan yang perlu diselesaikan adalah sebagai berikut:

1. Permasalahan intern Posyantek (hasil diskusi dengan pengurus posyantek, 2016).

a. Sumber Daya Manusia yang ada belum sesuai dengan pengembangan dari Posyantek itu sendiri

b. Pembiayaan / permodalan masih mengandalkan bantuan baik dari pusat maupun dari daerah.

c. Sekretariat belum dapat berdiri sendiri.

d. Perlu adanya stimulasi untuk memberi motivasi kepada pengurus dan kader dalam mengembangkan Posyantek yang ada.

e. Kepemilikan peralatan teknologi tepat guna yang masih terbatas. 
f. Perlunya perluasan jaringan kerja dalam pengembangan produk peralatan maupun jaringan pasaran dan permodalan.

2. Permasalahan ekstern Posyantek (data BPBD Bangdes Provinsi Riau).

a. Masyarakat kurang mengenal dan memanfaatkan Posyantek sebagai pusat informasi teknologi tepat guna.

b. Kurangnya kemitraan dalam membina kader-kader Posyantek dalam mengembangkan teknologi tepat guna.

c. Perlunya perluasan jaringan kerja dalam pengembangan produk peralatan maupun jaringan pasar dan investor modal.

Penanganan yang ditawarkan kalangan akademisi atau perguruan tinggi kepada kader posyatek, UMKM dan Masyarakat adalah sebagai berikut:

1. Memberikan wawasan kepada kader posyatek, UMKM dan Masyarakat tentang informasi perkembangan teknologi tepat guna yang mukhtahir.

2. Memberikan transfer pengetahuan kepada kader posyatek, UMKM dan Masyarakat tentang berbagai informasi teknologi tepat guna yang dapat dikembangkan pada Posyantek baik didanai pemerintah, perguruan tinggi maupun dari perusahaan swasta melalui $C S R$-nya, melalui kegiatan pelatihan.

3. Melaksanakan Focus Group Discusion (FGD) kepada mitra untuk menggali potensi yang dimiliki kecamatan Pasir penyu khususnya, dengan melakukan pemetaan terhadap hasil Teknologi Tepat Guna serta memberikan pendekatan Operasi dan Pemeliharaan (OP) yang baik dan benar terhadap hasil Teknologi Tepat Guna yang ada pada Posyantek.

4. Memberikan keterampilan atau skill melalui kegiatan On The Job Training (OJT) untuk dapat membuat usulan pengajuan dana dalam pengembangan Teknologi Tepat Guna.

\section{Pembahasan}

Pengurus Posyantek Bina Usaha mempunyai latar belakang pendidikan dan profesi yang beragam, mulai dari lulusan sekolah dasar sampai dengan sarjana Strata-1. Kader Posyantek umumnya berkerja dibidang wirausaha. Posyantek Bina Usaha merupakan suatu lembaga masyarakat dibawah pembinaan Camat Pasir Penyu dan pemilihan pengurusnya melalui suara terbanyak pada pertemuan yang di fasilitasi oleh BPMPD Bangdes Kabupaten 
dan pihak kecamatan. Namun ada hal yang menarik untuk dikemukakan adalah adanya kesamaan pandangan terhadap nilai penting posyantek bagi masyarakat dan UMKM Kecamatan, meskipun mereka mempunyai latar belakang pendidikan dan profesi yang berbeda. Terlihat dari hubungan komunikasi antara kader sudah terjalin dengan baik dan saling membantu dan berkomitmen dalam bekerja melayani masyarakat sebaik mungkin melalui pembinaan posyantek, namun masih mengalami kesulitan dalam pengembangan posyantek akibat keterbatasan pengetahuan teknologi, fasilitas prasarana dan permodalan.

Dari hasil kunjungan lapangan dan melakukan diskusi serta wawancara terhadap responden dihasilkan bahwa kader posyatek telah mampu melakukan pemetaan terhadap kebutuhan masyarakat dan UMKM terhadap alat-alat Teknologi Tepat Guna, sehingga kader posyantek dapat membantu masyarakat dan UMKM dalam memberikan pelayanan teknis, informasi berbagai jenis alat Teknologi Tepat Guna. berupa berbagai pelatihan keterampilan ataupun sosialisi informasi yang terkait dengan penguatan UMKM, biasanya kegiatan-kegiatan ini dilakukan sebagai bentuk kerjasama dengan lembaga terkait seperti Dinas Koperasi dan UKM, perindustrian dan perdagangan serta perguruan tinggi. Namun Posyatek Bina Usaha masih mempunyai kendala terhadap kurangnya kepemilikan peralatan Teknologi Tepat Guna. Hal ini membuat keterlambatan dalam memberikan pelayanan kepada usaha binaan posyantek.

Peran lembaga Pos Pelayanan Teknologi yang mempunyai fungsi intermediasi antara komunitas pengguna teknologi dengan pemilik / pencipta teknologi. Berdasarkan Fungsi inilah yang membuat posyatek menjadi sarana strategis dalam sinkronisasi antara kerja dan kinerja penelitian dan pengembangan dengan kebutuhan masyarakat. Tantangannya adalah bagaimana agar fungsi tersebut memberikan dampak bermakna bagi penguatan ekonomi rakyat khususnya usaha mikro kecil menengah. Fungsi intermediasi inilah yang diselenggarakan oleh Posyantek B in a Us a ha Kecamatan Pasir Penyu melalui berbagai kegiatan yang menghubungkan sumber teknologi, pemerintah, perguruan tinggi, badan usaha dan masyarakat. Misalnya pelayanan informasi teknologi tepat guna melalui sosialisasi kepada para Kepala Desa, BPD, LPMD, Karang Taruna melalui komunikasi langsung, menyiapkan informasi jaringan pasar dari produkproduk yang dihasilkan oleh masyarakat dan UMKM, dan mengikutsertakan hasil produk-produk UMKM pada berbagai jenis kegiatan pameran dan peragaan teknologi tepat guna setingkat kabupaten, provinsi maupun nasional. 
Sesuai dengan Peraturan Bersama Menteri Negara Riset dan Teknologi dan Menteri Dalam Negeri Republik Indonesia No 03 Tahun 2012 dan Nomor 36 Tahun 2012 tentang Penguatan Sistem Inovasi Daerah yang menegaskan bahwa untuk menumbuh-kembangkan inovasi yang dilakukan diperlukannya kerjasama antar institusi pemerintah, pemerintahan daerah, lembaga kelitbangan, lembaga pendidikan, lembaga penunjang inovasi, dunia usaha,dan masyarakat di daerah di dalam sebuah sistem yang dinamakan sistem inovasi daerah atau SIDa. Hal inilah yang melandasi kalangan akademisi melakukan kerjasama dalam mengembangkan Teknologi Tepat Guna dan Kelembagaan Posyantek. Diantaranya dengan melakukan penelitian terhadap hasil produksi Teknologi Tepat Guna sehingga dapat membantu dalam mengembangkannya menjadi lebih baik dan mempunyai daya saing ketika dipasarkan seperti penelitian tentang pengawetan batok kelapa yang digunakan sebagai bahan dasar pembuatan lantai keramik. Untuk segi kelembagaan dilakukan dengan memberikan motivasi dan pertukaran informasi dalam membangun suatu sistem yg efektif dan efisien guna mengembangkan kelembagaan Posyantek seperti pelatihan peningkatan kelembagaan posyantek, pelatihan pengelolaan sumber informasi melalui jaringan Internet dan lain-lain.

Hasil karya-karya Teknologi Tepat Guna yang dihasilkan oleh masyarakat Kecamatan pasir penyu melalui pembinaan dan pendampingan Pos Pelayanan Teknologi Bina Usaha telah banyak memperoleh penghargaan ditingkat lokal maupun nasional. Tetapi yang terpenting adalah peran intermediasi yang diselenggarakan oleh para kader posyantek ini telah mampu membantu UMKM meningkatkan hasil kinerjanya baik melalui teknologi tepat guna yang diciptakan maupun ditingkatkan. Penyebaran inovasi yang diterapkan sebagai kegiatan usaha diharapkan dapat disebarluaskan di luar wilayah kecamatan Pasir Penyu.

\subsection{Simpulan}

Dari semua tahapan kegiatan penelitian yang dilakukan pada posyantek Bina Usaha dapat disimpulkan sebagai berikut:

1. Posyantek Bina Usaha berhasil menjadi jembatan penghubung bagi pemenuhan kebutuhan masyarakat terhadap Teknologi Tepat Guna.

2. Adanya Peran serta perguruan tinggi dalam meningkatkan kapasitas dan kemampuan masyarakat dalam mengembangkan Teknologi Tepat Guna dan memberi motivasi dan informasi mukhtahir demi peningkatan kelembagaan posyantek. 
3. Pemetaan terhadap kebutuhan Teknologi Tepat Guna telah dilaksanakan namun tidak dibarengi dengan penambahan kepemilikan terhadap hasil Teknologi Tepat Guna.

\subsection{Saran}

Dari semua data yang ada disarankan :

1. Perlunya mensosialisasikan kepada masyarakat luas tentang fungsi dan peranan posyantek di masyarakat luas, sehingga dapat membuka pandangan dan pemikiran masyarakat tentang pentingnya keberadaan posyantek di masyarakat terutama pengguna Teknlogi Tepat Guna

2. Diharapkan ada kontribusi lanjutan dari kalangan akademisi atau perguruan tinggi agar target utama yang diharapkan dapat terlaksana yaitu terpenuhi semua kebutuhan masyarakat terhadap Teknologi Tepat guna dan pelayanan posyantek sehingga dapat membantu perekonomian masyarakat.

3. Ada sinergi dari semua pihak (pemerintah, swasta dan masyarakat) untuk mewujudkan pengembangan Teknologi Tepat Guna dan pelayanan Posyantek kepada masyarakat terutama UMKM .

\section{UCAPAN TERIMA KASIH.}

Terimakasih disampaikan pada rekan-rekan di komunitas Posyantek Bina Usaha Kecamatan Pasir Penyu, Pemerintah kabupaten Indragiri Hulu, Dinas BPMPD Bangdes terhadap informasi data dan sumbangsi pemikiran, sehingga kami mendapat Pelajaran terpenting dari anda semua tentang mengartikan kata "melayani” masyarakat.

\section{DAFTAR PUSTAKA}

Anonimus, 2016. Kabupaten Indragiri Hulu dalam Angka. Badan Pusat Statistik Kabupaten Indragiri Hulu.

Anonimus. The Global Competitiveness Report. http://www.weforum.org/reports/globalcompetitiveness-report-2014-2015. Diakses tanggal 15 September 2016).

Carolina, Sudaryanto.j, Setyabudhi.A, 2014. Posyantek sebagai Komponen Ekosistem Inovasi untuk pemeberdayaan UMKM. 
Kementrian Dalam Negeri Republik Indonesia, 2010, Peraturan Menteri dalam negeri Nomor 20 Tahun 2010 Tentang pemberdayaan msyarakat melaluipengelolaan Teknologi Tepat Guna, Direktorat Jenderal Pemberdayaan Masyarakat dan Desa.

Menteri Negara Riset dan Teknologi Republik Indonesia dan Menteri Dalam Negeri Republik Indonesia, 2012, Peraturan bersama Menteri Negara Riset dan Teknologi Republik Indonesia dan Menteri Dalam Negeri Republik Indonesia Nomor 03 Tahun 2012 danNomor 36 Tahun 2012 dan Penguatan Sistem Inovasi Daerah. 